\title{
Hepatitis $C$ virus infection and risk factors in health-care workers at Ain Shams University Hospitals, Cairo, Egypt
}

O. Okasha, ${ }^{7}$ A. Munier, ${ }^{2}$ E. Delarocque-Astagneau, ${ }^{2}$ M. El Houssinie, ${ }^{7}$ M. Rafik, ${ }^{3}$ H. Bassim, ${ }^{3}$ M. Abdel Hamid, ${ }^{4,5}$ M.K. Mohamed ${ }^{7}$ and A. Fontanet ${ }^{2,6}$

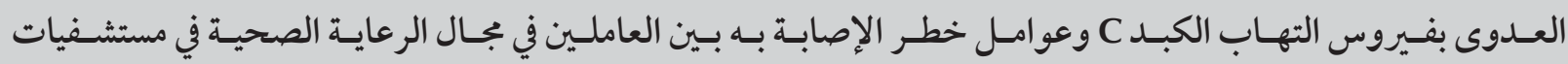

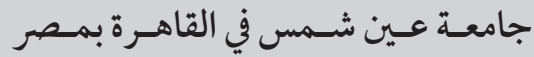

$$
\begin{aligned}
& \text { عمر عكاشة، ألين مونيير، اليز ابيث ديلاروك في - أستانيو، مصطفى الحسيني، منى رفيت، هادية بسيم، محمد عبد الحميد، مصطفى كمال محمد، أرنو فونتانيه }
\end{aligned}
$$

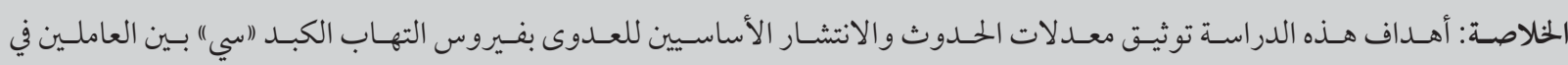

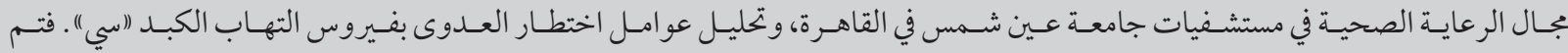

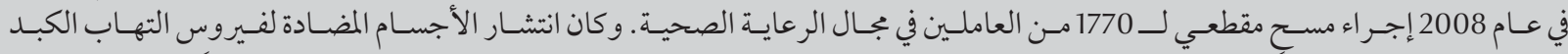

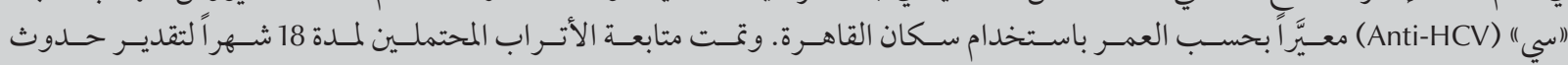

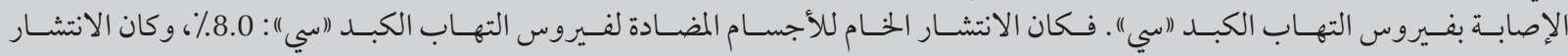

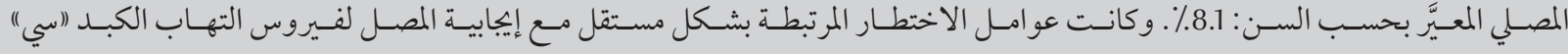

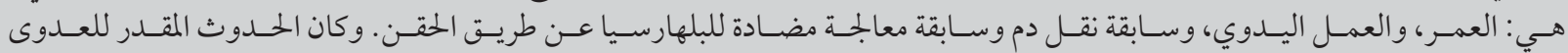

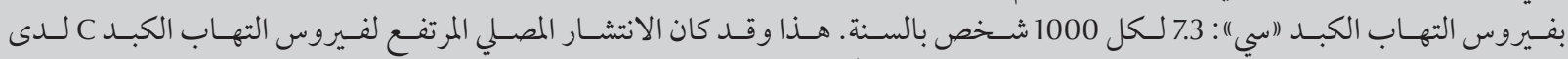

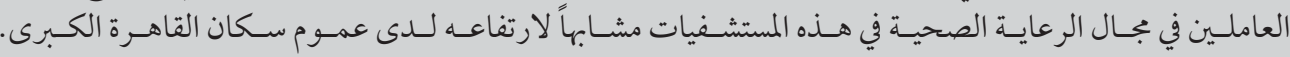

ABSTRACT The objectives of this study were to document the background prevalence and incidence of HCV infection among HCWs in Ain Shams University Hospitals in Cairo and analyse the risk factors for HCV infection. A cross-sectional survey was conducted in 2008 among $1770 \mathrm{HCW}$. Anti-HCV prevalence was age-standardized using the Cairo population. A prospective cohort was followed for a period of 18 months to estimate HCV incidence. The crude anti-HCV prevalence was $8.0 \%$ and the age-standardized seroprevalence was $8.1 \%$. Risk factors independently associated with HCV seropositivity were: age, manual worker, history of blood transfusions and history of parenteral anti-schistosomiasis treatment. The estimated incidence of HCV infection was 7.3 per 1000 person-years. HCWs in this setting had a similar high HCV seroprevalence as the general population of greater Cairo.

Infection par le virus de l'hépatite $C$ et facteurs de risque chez les agents de santé de l'hôpital universitaire Ain Shams au Caire (Égypte)

RÉSUMÉ Les objectifs de la présente étude étaient de documenter la prévalence et l'incidence de fond de l'infection par le virus de I'hépatite C chez les agents de santé de I'hôpital universitaire Ain Shams du Caire et d'analyser les facteurs de risque de contracter une infection par le virus de l'hépatite C. Une enquête transversale a été menée en 2008 auprès de 1770 agents de santé. La prévalence des anticorps contre le virus de l'hépatite C a été normalisée pour l'âge par rapport à la population du Caire. Une cohorte prospective a été suivie pendant 18 mois pour estimer l'incidence de l'infection par le virus de l'hépatite C. La prévalence brute des anticorps contre le virus de l'hépatite C était de 8,0 \% et la séroprévalence normalisée pour l'âge était de 8,1 \%. Les facteurs de risque indépendamment associés à une séropositivité pour le virus de l'hépatite C étaient les suivants : l'âge, le travail manuel, des antécédents de transfusion sanguine ainsi que des antécédents de traitement parentéral contre la schistosomiase. L'incidence de l'infection par le virus de l'hépatite C a été estimée à 7,3 pour 1000 personnes par an. Les agents de santé de cet établissement hospitalier avaient une séroprévalence du virus de l’hépatite C aussi élevée que la population générale du Grand Caire.

${ }^{7}$ Department of Community, Environmental and Occupational Medicine; ${ }^{3}$ Department of Clinical Pathology, Faculty of Medicine, Ain Shams University, Cairo, Egypt (Correspondence to O. Okasha: omar.okasha@uta.fi). ${ }^{2}$ Emerging Diseases Epidemiology Unit, Institut Pasteur, Paris, France. ${ }^{4}$ Viral Hepatitis Research Laboratory, National Hepatology and Tropical Medicine Research Institute, Cairo, Egypt. ${ }^{5}$ Department of Microbiology, Faculty of Medicine, Minya University, Minya, Egypt. ${ }^{6}$ Conservatoire National des Arts et Mériers, Paris, France.

Received 07/07/14; accepted: 22/01/15 


\section{Introduction}

Over 150 million people are infected with hepatitis $\mathrm{C}$ virus ( $\mathrm{HCV}$ ) worldwide (1). Egypt has the highest $\mathrm{HCV}$ seroprevalence, estimated at $14.7 \%$ in a study using a nationwide representative sample of the population aged $15-59$ years $(2,3)$. The origin of the epidemic is believed to be related to mass antischistosomal parenteral treatment campaigns conducted in the 1960s-80s using insufficiently sterilized injection material (4). Evidence of ongoing transmission of $\mathrm{HCV}$ that is associated with health-care settings has consistently accumulated over recent years $(5,6)$. Therefore, healthcare workers (HCWs) in Egypt are at particular risk of HCV infection and other bloodborne pathogens (7), with an estimated annual number of needlestick injuries of 4.9 per HCW (8), a high reservoir of HCV infection in the patient population and an estimated $66 \%$ of $\mathrm{HCV}$ infections being attributed to occupational exposures (9).

There are few comprehensive studies on the current prevalence among HCWs in Egypt, with reported HCV seroprevalence ranging from $7.7 \%$ to $16.6 \%(10,11)$. In 2002, national guidelines for control of nosocomial infections were developed and adopted by the Ministry of Health and Population (12) and in the 2008 Egyptian National Control Strategy for Viral Hepatitis, HCWs comprised an important target for future control strategies. Consequently, a surveillance programme of occupational blood exposures was initiated in Ain Shams University Hospitals (ASUHs) in 2008 in collaboration between the departments of infection control and community medicine. Data from the surveillance programme enabled us to examine the following objectives: to estimate the background seroprevalence of HCV and HBV infection among HCWs; to identify factors associated with $\mathrm{HCV}$ infection; and to estimate $\mathrm{HCV}$ incidence among HCWs.

\section{Methods}

\section{Study setting}

The study took place in ASUHs, a major tertiary-care teaching hospital in Cairo, with over 3200 beds and 4500 employees working in 4 departments: internal medicine, obstetrics/gynaecology, paediatrics and surgery, each including several wards. Each year around 1300 new interns, i.e. physicians- and nursesin-training, are assigned to different departments. The study protocol was approved by the ethics committees at the National Hepatology and Tropical Medicine Research Institute (NHTMRI) in Cairo (accreditation number: IORG0003280).

\section{Study population and sampling methods}

A cross-sectional prevalence survey was conducted between August and October 2008. Sampling for the crosssectional survey was carried out by means of convenience sampling, i.e. all HCWs who were present at the time of conducting the survey were invited to participate. The hospital workforce census in 2008 was 4523 employees, including 1300 interns; only data on the distribution of occupational groups were available for the 2008 employee census. With an expected $2300 \mathrm{HCWs}$ participating in the survey and an $\mathrm{HCV}$ antibody prevalence of $10 \%$, the precision around the estimate was calculated at $1.2 \%$ (alpha $=0.05)$. That same sample size would give $80 \%$ power to consider statistically significant associations with $\mathrm{HCV}$ infection characterized by $\mathrm{OR}$ of 1.8 or more, for exposures at least 10\% prevalent among $\mathrm{HCV}$-negative participants (alpha $=0.05 ; 2$-sided tests).

A subsample of anti-HCV-negative HCWs was invited to participate in an 18-month cohort to assess HCV incidence. Sampling for the cohort study was carried out by inviting all HCWs who tested negative for both HCV and $\mathrm{HBV}$ in the cross-sectional survey $(n=$ 1603) to join the cohort study. Recruitment of HCWs stopped prematurely after 417 HCWs were included, as a result of unexpected funding reductions.

The sampling process for the study is illustrated in Figure 1.

\section{Data collection}

\section{Questionnaire}

Informed, written consent in Arabic was obtained from participants or from guardians of those younger than 18 years of age. A close-ended questionnaire was administered by a nurse. The questionnaire included questions on sociodemographic characteristics and past risk exposures in the community (e.g. injection practices, sharing of toothbrushes and razors, shaving at the barber's shop), iatrogenic exposures (e.g. hospital admission, invasive and non-invasive procedure, blood transfusion, bilharziasis treatment and obstetric history) and occupational exposures (e.g. syringe/sharps injury, body fluids and $\mathrm{HBV}$ vaccination). A $10 \mathrm{~mL}$ blood sample was collected by the nurse.

The cohort participants were reexamined during 2 successive rounds with the questionnaire on recent risk exposures and blood sample collection, first in July to September 2009, then in February to April 2010.

\section{Laboratory testing}

Sera in the cross-sectional survey were tested in ASUH's central laboratory using HCV enzyme immunoassay (EIA) 3.0 (Abbott Laboratories) for anti-HCV antibodies, Auszyme monoclonal 3rdgeneration EIA (Abbot Laboratories) for HBs antigen, and routine tests for alanine transaminase (ALT). Samples positive for anti-HCV antibodies were tested again and those testing positive by the 2 serological tests were considered positive for anti-HCV. Samples with discordant results were considered negative. 


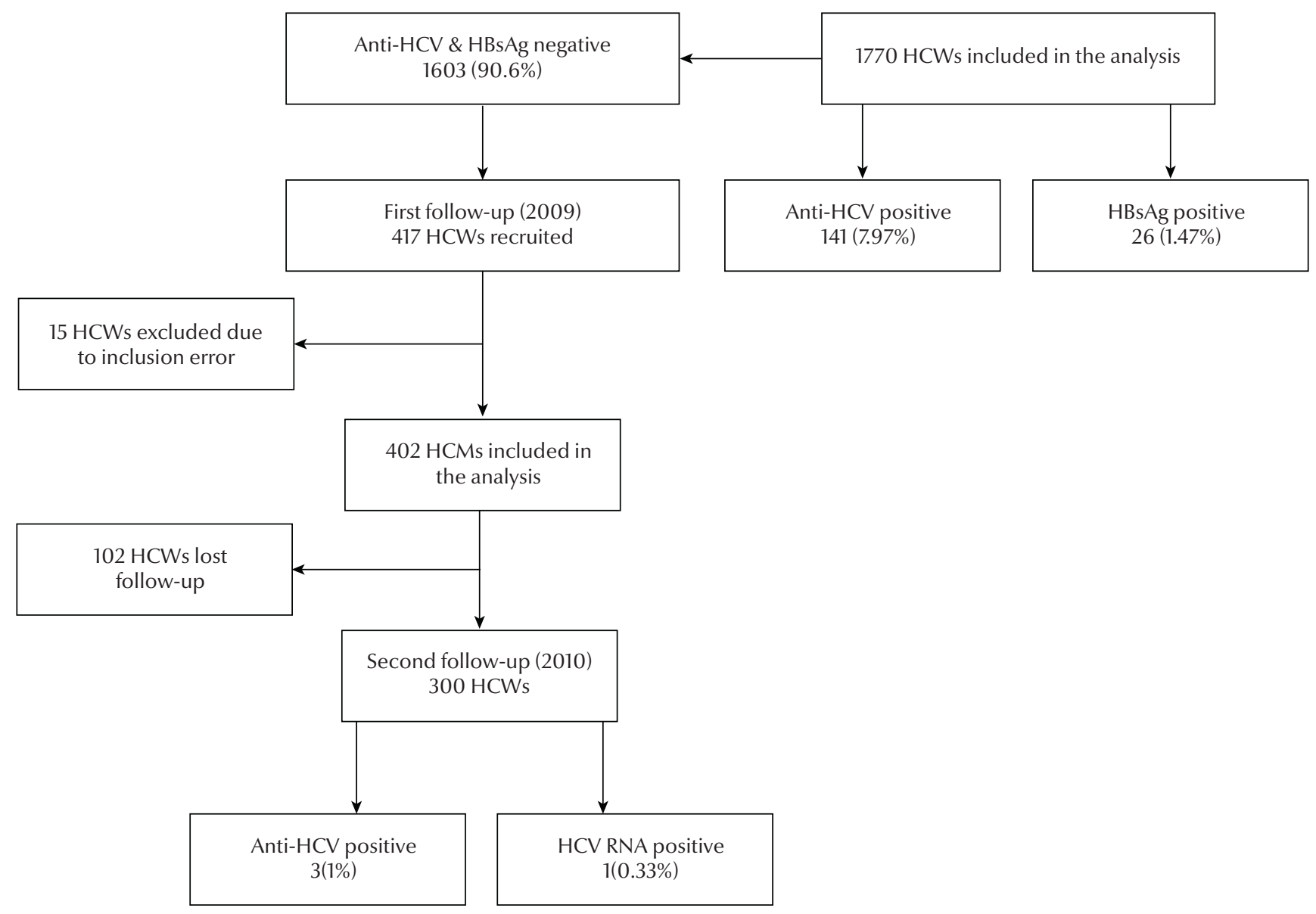

Figure 1 Flowchart of participants in the study at Ain Shams University Hospitals, Cairo, 2008 (HCW = health-care workers, anti-HCV = hepatitis C virus antibody, HBsAg = hepatitis B surface antigen, HCV RNA = hepatitis C virus ribonucleic acid)

Sera for the cohort study were tested in the Viral Hepatitis Research Laboratory at the National Hepatology and Tropical Medicine Research Institute in Cairo (NHTMRI) for anti-HCV antibodies using the same technique as in ASUHs. Cohort samples with positive anti-HCV antibodies were tested for HCV-RNA using a one-step inhouse reverse transcriptase/ploymrease chain reaction assay (13) and tested for ALT.

Participants who had positive anti-HCV antibodies were referred by the study coordinator in a timely manner to the NHTMRI hepatology clinic for further evaluation and treatment according to standard practices.

\section{Statistical analysis}

Data analysis was performed using Stata statistical package, version 11. Prevalence estimates of $\mathrm{HCV}$ (anti-HCV) and HBV (HBsAg) were computed with their $95 \%$ confidence interval (CI). Population data of greater Cairo was extracted from the 2008 Demographic and Health Survey database (2), to calculate the agestandardized prevalence of anti-HCV among HCWs in the survey study. Estimate of HCV incidence was obtained by the number of new $\mathrm{HCV}$ infections (defined as seroconversion during cohort follow-up) divided by the total number of person-years of follow-up in the cohort.

Characteristics of participants with and without HCV antibodies were compared using Student t-test and chi-squared test for continuous and categorical variables, respectively. All exposures were tested for association with anti-HCV positivity in univariate and age-adjusted analyses with calculation of odds ratio (OR) and 95\% confidence interval $(\mathrm{CI})$. Age adjustment was performed by including age as continuous variable in the model, after verification of the assumption of linearity in the relationship between age and the outcome. A sensitivity analysis showed similar results, in which age was adjusted for as a categorical variable (data not shown). Variables with $P$-values $<0.25$ in the age-adjusted models were entered in a multivariate logistic regression model and removed in a manual backward procedure using a likelihood ratio test at 
each step. Variables were kept in the final model if $P<0.05$.

\section{Results}

\section{Cross-sectional survey}

\section{Characteristics of the study population}

A comparison between the occupational groups of HCWs who were included in the cross-sectional survey and the total employee population in 2008 is shown in Table 1. Although convenience sampling was used, the 2 groups were similar, except for the under-representation of physicians-intraining.

A total of 1770 HCWs (39.1\% of total hospital employees) were included in the survey (Figure 1). The mean age was 34 years (range $16-65$ years) and $74 \%$ were females. Over $60 \%$ of subjects were married at the time of survey. Almost half of HCWs were nurses (47.2\%), 21.7\% were manual workers and $13.5 \%$ were medical doctors (including 9.1\% residents and senior doctors and $4.4 \%$ physicians-in-training) (Table 2). Most hospital departments were covered in the survey, $21.6 \%$ of HCWs worked in surgery and $20.5 \%$ in internal medicine. Of the participants $20.9 \%$ reported having periodic testing for hepatitis markers and $48.4 \%$ had received at least one dose of HBV vaccination.

\section{Prevalence of $\mathrm{HCV}, \mathrm{HBV}$ markers and $A L T$ results}

The overall crude prevalence of antiHCV was $141 / 1770$ (8.0\%; 95\% CI: $6.7-9.2 \%)$ and the age-standardized anti-HCV prevalence was $8.1 \%$ (95\% CI: 6.8-9.3\%). The HCV prevalence among our sample of HCWs was not significantly different than the population of greater Cairo $[10.4 \%$ (95\% CI: $8.2-12.6 \%)](P=0.127)$, based on Egypt Demographic and Health Survey data (2). Figure 2 shows the $\mathrm{HCV}$ prevalence by age and sex of the

\begin{tabular}{|c|c|c|c|c|c|}
\hline $\begin{array}{l}\text { Table } 1 \text { Occupational } p \\
\text { Hospitals compared w }\end{array}$ & $\begin{array}{l}\text { of heal } \\
\text { ose enr }\end{array}$ & $\begin{array}{l}\text { are wo } \\
d \text { in the }\end{array}$ & $\begin{array}{l}\text { in } \mathrm{Ai} \\
\text { valen }\end{array}$ & $\begin{array}{l}\text { Ims Un } \\
\text { idy }(n=\end{array}$ & $\begin{array}{l}\text { rsity } \\
\text { 23) }\end{array}$ \\
\hline Occupational group & Hosp & census & Stuc & mple & $P$-value ${ }^{a}$ \\
\hline & No. & $\%$ & No. & $\%$ & \\
\hline Doctor $^{b}$ & 286 & 6.3 & 161 & 9.1 & 0.275 \\
\hline Physician-in-training & 614 & 13.6 & 77 & 4.4 & 0.022 \\
\hline Nurse $^{c}$ & 2126 & 47.0 & 835 & 47.2 & 0.922 \\
\hline Manual worker & 1088 & 24.1 & 383 & 21.7 & 0.341 \\
\hline Laboratory technician & 249 & 5.5 & 84 & 4.8 & 0.805 \\
\hline Pharmacist & 160 & 3.5 & 150 & 8.5 & 0.062 \\
\hline Unknown & - & - & 80 & 4.5 & - \\
\hline Total & 4523 & 100.0 & 1770 & 100.0 & - \\
\hline
\end{tabular}

${ }^{a}$ Two-sample test of proportions.

${ }^{b}$ Includes residents and senior doctors; clncludes both nurses-in-training and qualified/practising nurses.

survey population compared with that of greater Cairo.

Among the 1770 HCWs, 26 (1.5\%; 95\% CI: $0.9-2.0 \%)$ were positive for HBsAg. The mean ALT level was 18.6 $\mathrm{U} / \mathrm{L}$ (range $2-188 \mathrm{U} / \mathrm{L}$ ) and 92 (5.2\%) of HCWs had ALT level above the upper reference limit $(41 \mathrm{U} / \mathrm{L})$. Higher ALT was significantly associated with anti-HCV seropositivity (OR 4.9; 95\% CI: 2.9-8.1, for ALT > 41 versus $<41$ $\mathrm{U} / \mathrm{L})(P<0.001)$.

\section{Risk factors associated with $\mathrm{HCV}$ se- ropositivity}

Age had a significant association with HCV seropositivity $(P<0.001)$, with 50-54-year-olds having almost 10 times higher risk of HCV seropositivity compared with those aged $<25$ years (OR 9.8; 95\% CI: 4.7-20.4) (Table 2). In the age-adjusted analysis, only the occupation of participants was significantly associated with seropositivity $(P$ $<0.001$ ), with manual workers (OR 4.9; 95\% CI: 1.7-13.9) and laboratory technicians (OR 3.9; 95\% CI: 1.1-13.0) being at higher risk compared with medical doctors.

Almost half of participants (46.3\%) reported having received more than 10 injections in their lifetime (Table 2), and the majority $(81 \%)$ of them had those injections given by a medical doctor. The main routes of injection were intramuscular $(85 \%)$ or intravenous
(69\%). A majority of the men (80.2\%, 328/409) reported having their beard shaved at the barber's shop. In the ageadjusted analysis, only shaving with used razors at the barber's shop was significantly associated with HCV seropositivity $(P=0.03)$, yet only $5 \mathrm{HCWs}$ reported this exposure.

Around half of HCWs (53.3\%) had been admitted to hospital during their lifetime (Table 3), of whom $47.7 \%$ (450/944) had been admitted more than once. Only 119 HCWs (6.7\%) had received a blood transfusion in their lifetime. After age-adjustment the number of blood transfusions was marginally associated with seropositivity $(P=0.068)$. Among the different procedures done in hospital, sutures and intravenous catheterization were reported more than other procedures (31.4\% and $26.8 \%$ respectively). However, none of these procedures were associated with seropositivity in the ageadjusted model.

Some of the HCWs $(104,5.9 \%)$ had had bilharziasis and 27 (26.0\%) of them reported having received parenteral antischistosomal therapy. Both types of exposure were significantly associated with HCV seropositivity in the age-adjusted analysis $(P<0.001)$. Specifically, those having received parenteral antischistosomal therapy had a 6-fold increased odds of HCV infection 


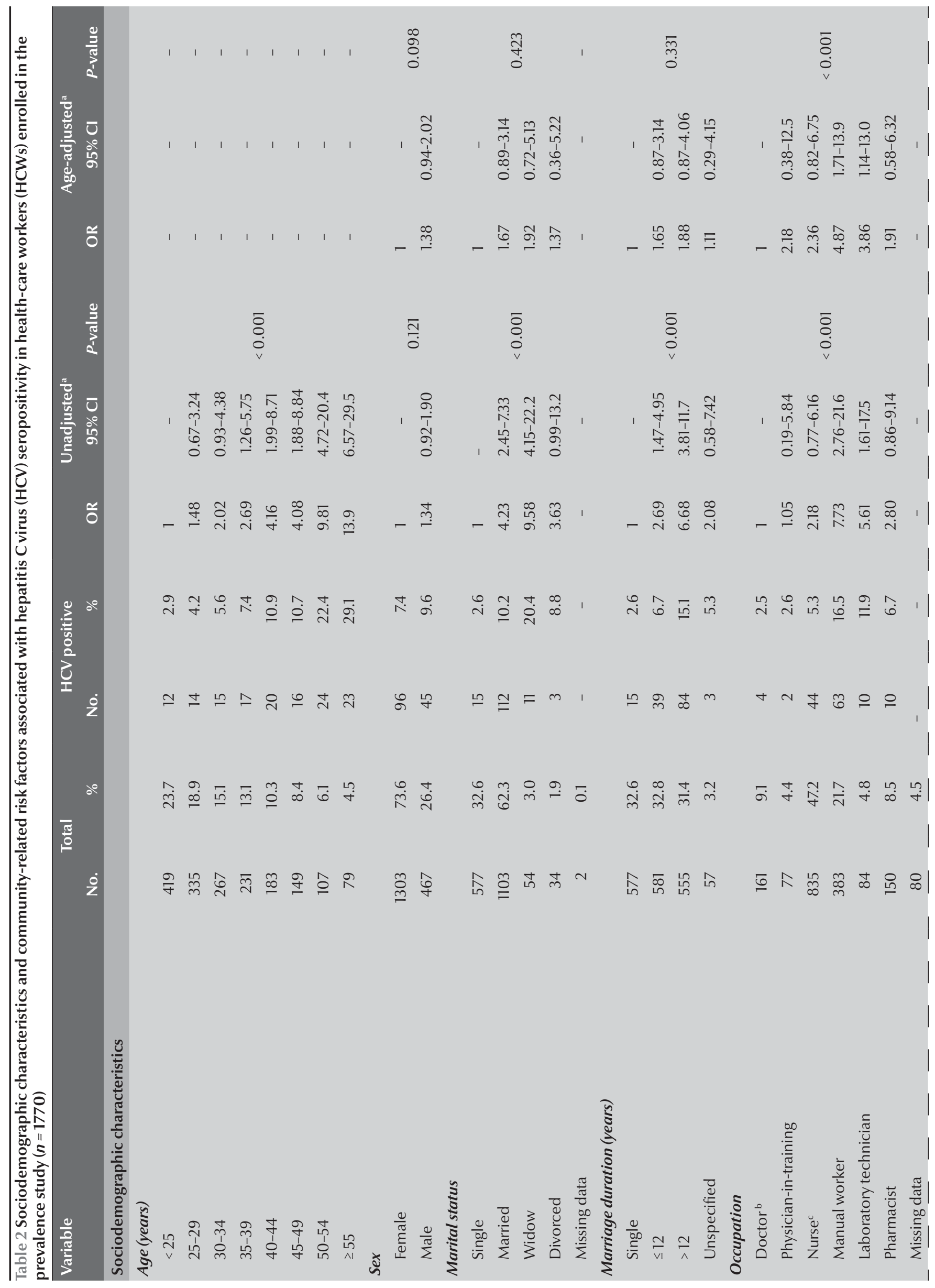




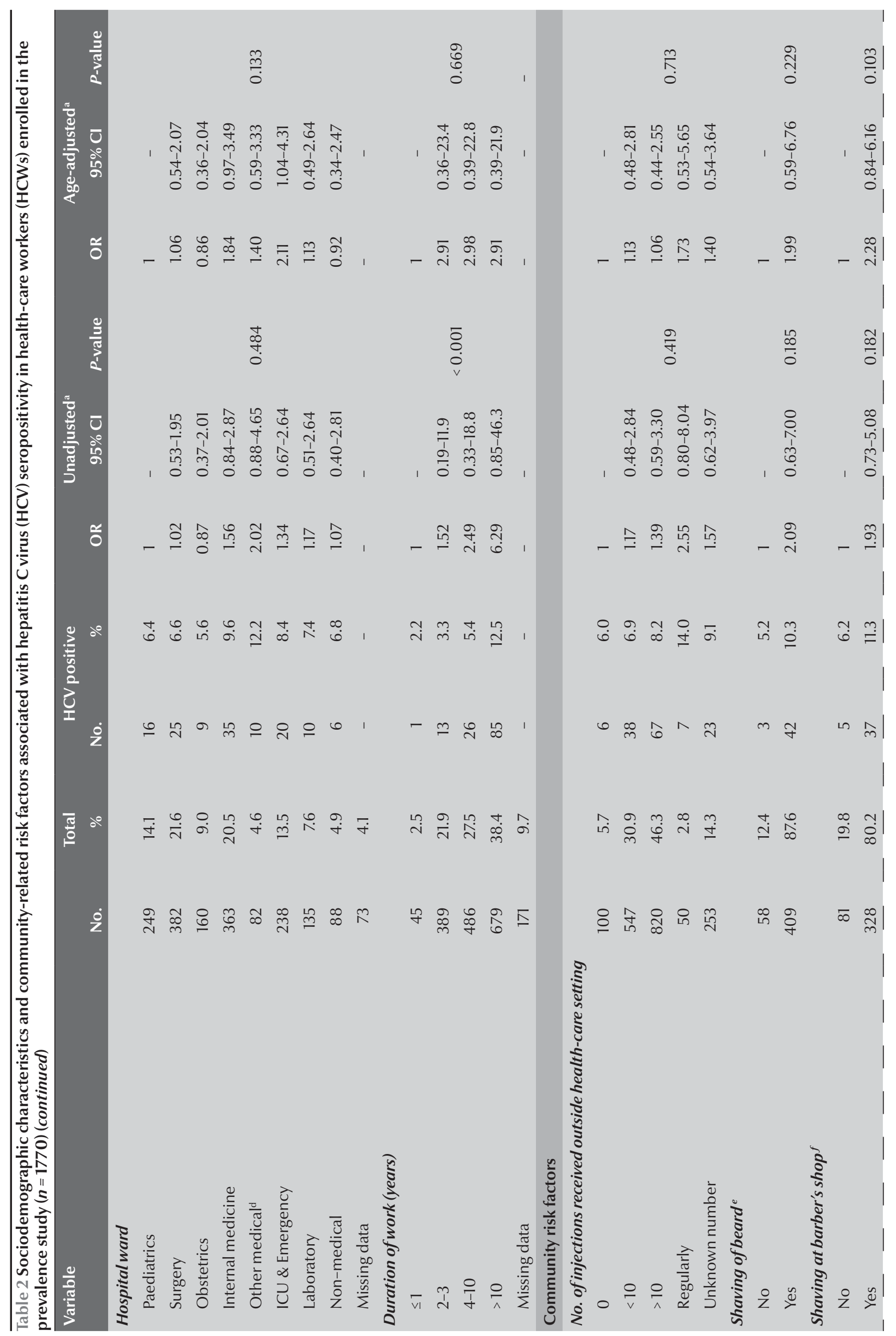




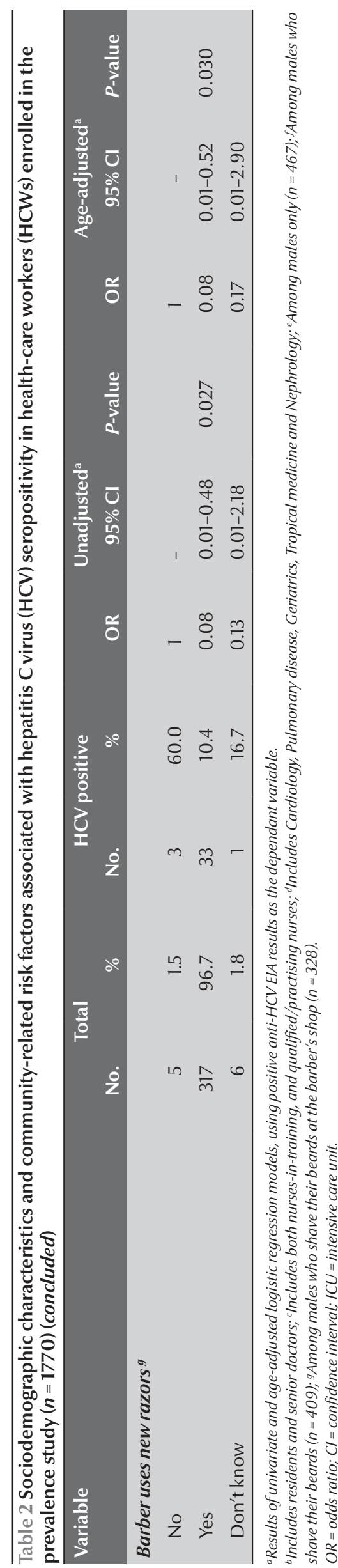

$2 \mathrm{a}$

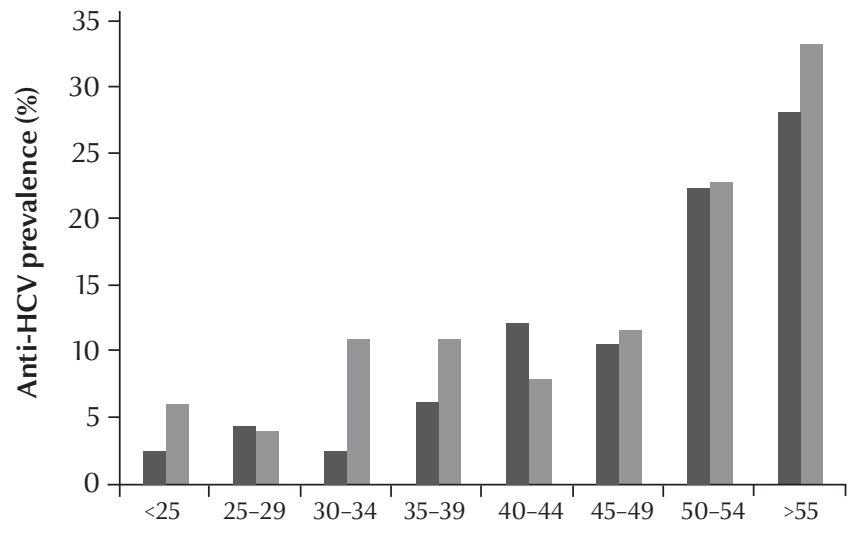

Age groups (years)

Females Males

$2 b$

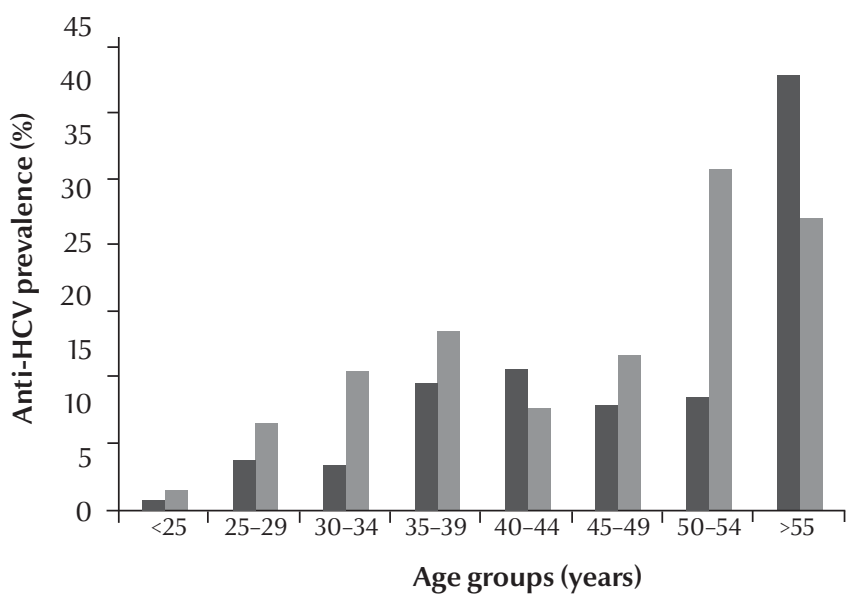

Figure 2 Prevalence of anti-hepatitis C virus (HCV) antibodies in (a) Ain Shams University Hospitals, (b) population of Cairo (2), stratified by age and sex

(95\% CI: 2.6-13.9) (Table 3). None of the obstetric-related procedures or dental treatment were associated with HCV seropositivity in the age-adjusted analysis.

Exposure to sharps injuries by syringes was reported by $67.1 \%$ of HCWs, and more than half of all HCWs reported having at least sharps injury per month (Table 3 ). Half of HCWs $(49.7 \%$, 879/1770 had ever been pricked without gloves and $83 \%$ of HCWs who wore gloves ever had tears in their gloves. Most HCWs reported exposure to blood ( $88.7 \%$,
1034/1166), and to a lesser extent to other fluids. In the age-adjusted analysis, none of the occupational exposures were significantly associated with $\mathrm{HCV}$ seropositivity.

\section{Multivariate logistic regression}

The results of multivariate logistic regression showed the following variables to be independently associated with anti-HCV seropositivity: age (OR of 2.01 for increase of 10 years of age, $P<$ 0.001 ); having received a large number of blood transfusions (OR 5.9; 95\% CI: $2.0-16.9 ; P=0.001)$, having had 


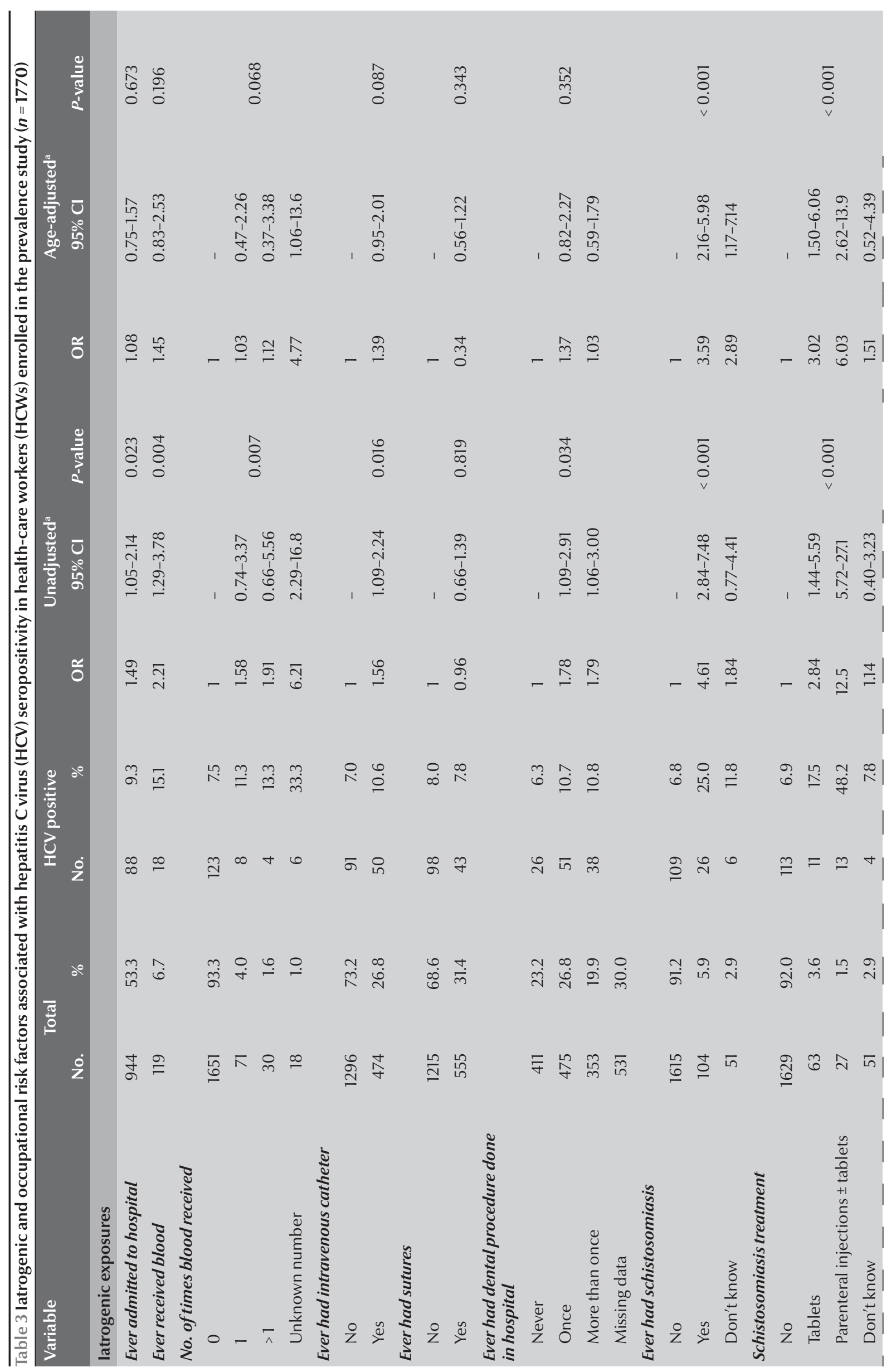




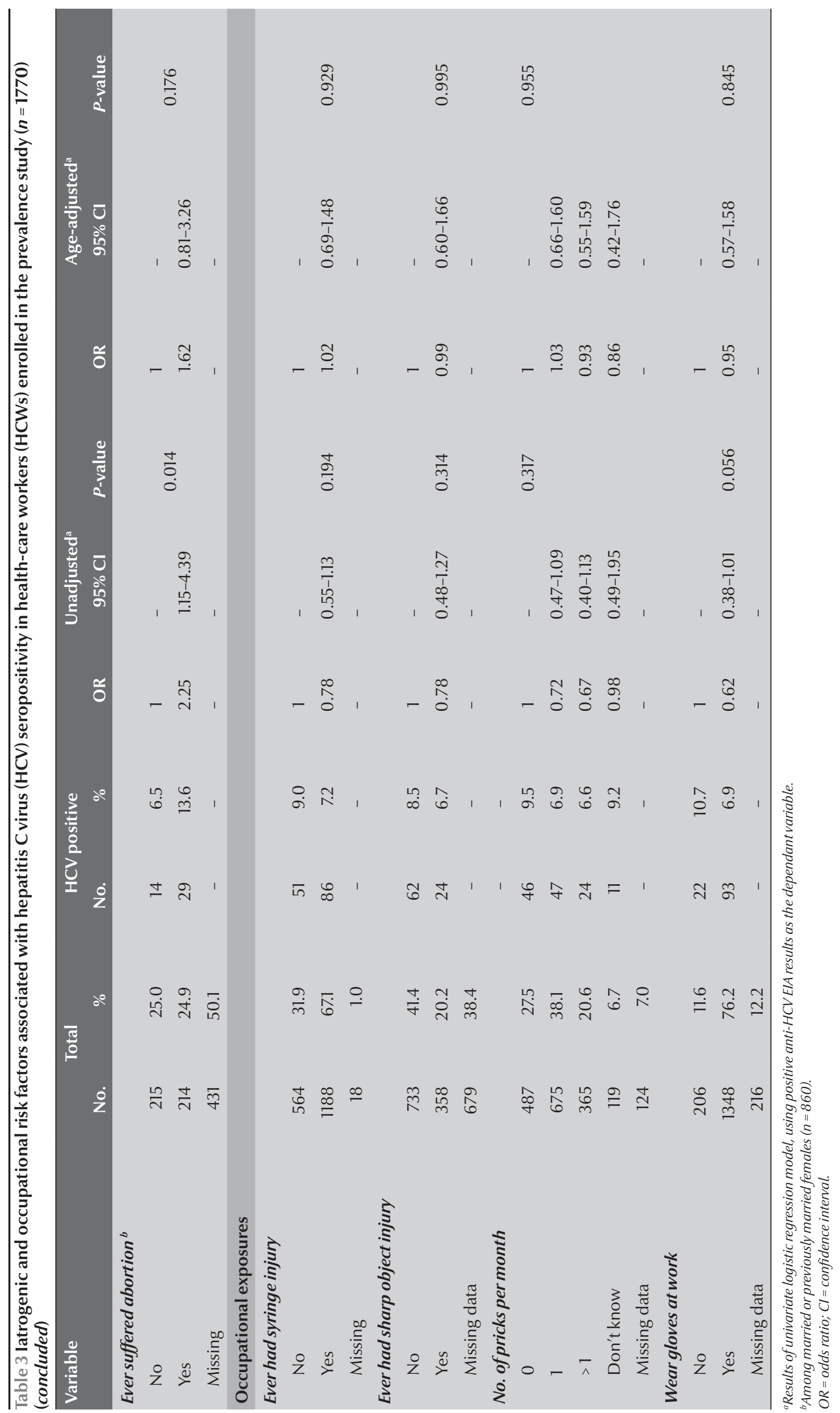




\begin{tabular}{|c|c|c|c|c|c|c|}
\hline \multirow[t]{2}{*}{ Variable } & \multicolumn{3}{|c|}{ Age-adjusted univariate analysis } & \multicolumn{3}{|c|}{ Multivariate analysis (final model) } \\
\hline & OR & $95 \% \mathrm{Cl}$ & $P$-value & OR & $95 \% \mathrm{Cl}$ & $P$-value \\
\hline Age per year & 1.07 & 1.06-1.09 & $<0.001$ & 1.07 & 1.05-1.09 & $<0.001$ \\
\hline \multicolumn{7}{|l|}{$\operatorname{Sex}^{a}$} \\
\hline Female & 1 & - & \multirow{2}{*}{0.098} & 1 & - & \multirow{2}{*}{0.972} \\
\hline Male & 1.38 & $0.94-2.02$ & & 1.01 & $0.62-1.64$ & \\
\hline \multicolumn{7}{|l|}{ Occupation } \\
\hline Doctor $^{b}$ & 1 & - & \multirow{6}{*}{$<0.001$} & 1 & - & \multirow{6}{*}{0.006} \\
\hline Physician-in-training & 2.18 & $0.38-12.5$ & & 2.09 & $0.36-12.2$ & \\
\hline Nurse $^{c}$ & 2.36 & $0.82-6.75$ & & 2.32 & $0.79-6.83$ & \\
\hline Manual worker & 4.87 & $1.71-13.9$ & & 4.28 & $1.48-12.4$ & \\
\hline Laboratory technician & 3.86 & $1.14-13.0$ & & 3.05 & $0.86-10.8$ & \\
\hline Pharmacist & 1.91 & $0.58-6.32$ & & 1.67 & $0.49-5.65$ & \\
\hline \multicolumn{7}{|c|}{$\begin{array}{l}\text { Ever received blood transfusion } \\
\text { (no. of times) }\end{array}$} \\
\hline 0 & 1 & - & & 1 & - & \\
\hline 1 & 1.03 & $0.47-2.26$ & \multirow{3}{*}{0.068} & 1.04 & $0.45-2.39$ & \multirow{3}{*}{0.033} \\
\hline$>1$ & 1.12 & $0.37-3.38$ & & 1.22 & $0.39-3.82$ & \\
\hline Many & 4.77 & $1.06-13.6$ & & 5.85 & $2.02-16.9$ & \\
\hline \multicolumn{7}{|c|}{ Treatment for schistosomiasis } \\
\hline No & 1 & - & & 1 & - & \multirow{4}{*}{$<0.001$} \\
\hline Tablets & 3.02 & $1.50-6.06$ & & 2.90 & $1.37-6.16$ & \\
\hline Injections \pm tablets & 6.03 & $2.62-13.9$ & $<0.001$ & 6.34 & $2.61-15.4$ & \\
\hline Don't know & 1.51 & $0.52-4.39$ & & 1.67 & $0.56-4.93$ & \\
\hline \multicolumn{7}{|l|}{ Hospital ward } \\
\hline Paediatrics & 1 & - & 0.133 & - & - & \multirow[t]{8}{*}{-} \\
\hline Surgery & 1.06 & $0.54-2.07$ & & - & - & \\
\hline Obstetrics & 0.86 & $0.36-2.04$ & & - & - & \\
\hline Internal medicine & 1.84 & $0.97-3.49$ & & - & - & \\
\hline Other medical $^{\mathrm{d}}$ & 1.40 & $0.59-3.33$ & & - & - & \\
\hline ICU \& Emergency & 2.11 & $1.04-4.31$ & & - & - & \\
\hline Laboratory & 1.13 & $0.49-2.64$ & & - & - & \\
\hline Non-medical & 0.92 & $0.34-2.47$ & & - & - & \\
\hline \multicolumn{7}{|l|}{ Sharing of razors } \\
\hline No & 1 & - & 0.145 & - & - & \multirow[t]{2}{*}{-} \\
\hline Yes & 1.75 & $0.86-3.56$ & & - & - & \\
\hline \multicolumn{7}{|l|}{ Shaving at barber's shop ${ }^{e}$} \\
\hline No & 1 & - & 0.103 & - & - & \multirow[t]{2}{*}{-} \\
\hline Yes & 2.28 & $0.84-6.16$ & & - & - & \\
\hline \multicolumn{7}{|c|}{ Intravenous catheterization } \\
\hline No & 1 & - & 0.087 & - & - & \multirow[t]{2}{*}{-} \\
\hline Yes & 1.39 & $0.95-2.01$ & & - & - & \\
\hline
\end{tabular}

${ }^{a}$ The variable sex was forced in the multivariate model.

${ }^{b}$ Includes residents and senior doctors; 'Includes both nurses-in-training and qualified/practising nurses; 'Includes Cardiology, Pulmonary disease, Geriatrics, Tropical medicine and Nephrology; ${ }^{e} F e m a l e s$ were included in the non-exposed reference category in the multivariate analysis.

$O R=$ odds ratio; $C I=$ confidence interval.

$I C U=$ Intensive care unit. 
treatment for bilharziasis with parenteral antischistosomal therapy (OR 6.3; 95\% CI: 2.6-15.4; $P<0.001)$ and being a manual worker (OR 4.3; 95\% CI: 1.5-12.4; $P<0.001$ ) (Table 4).

\section{Cohort study}

\section{Characteristics of the study population}

A total of $402 \mathrm{HCW}$ s were included in the cohort study. A comparison between the sociodemographic characteristics of HCWs selected in the cohort study and those not selected, i.e. HCV-EIA-negative HCWs in the cross-sectional survey $(n=1220)$, is shown in Table 5. The cohort study had a higher proportion of married female nurses and HCWs working in surgical departments; nevertheless the age distribution was similar to that of HCWs not selected from the sampling frame. The mean age of participants was 35 years (range 16-60 years). Females comprised $79.4 \%$ of participants and $74.9 \%$ of HCWs were married or previously married at the time of first interview. The breakdown by occupation showed $63.7 \%$ were nurses, $21.6 \%$ manual workers and $4.9 \%$ medical doctors. HCWs worked mainly in the surgical (32.6\%), obstetrics/gynaecology (26.4\%) and internal medicine (13.7\%) departments.

\section{HCV incidence}

Of the 402 HCWs who were followed for 12 months after the survey, 300 of them continued follow-up for an additional 6 months (i.e. 18 months of follow-up) with 2 blood samples taken. By the end of the follow-up, 4 HCWs had positive anti-HCV tests (seroconversion), including 1 who was viraemic (positive HCV RNA) at the 12-month interview and who remained as such until the end of follow-up. Regarding the 3 non-viraemic cases, 1 had seroconversion at the 12 -month visit and the remaining 2 at the 18-month (last) visit of follow-up. Over a total analysis time of 551 person-years, the estimated incidence of $\mathrm{HCV}$ infection was 7.3 per 1000 person-years (95\% CI: 2.7-19.4). The characteristics and

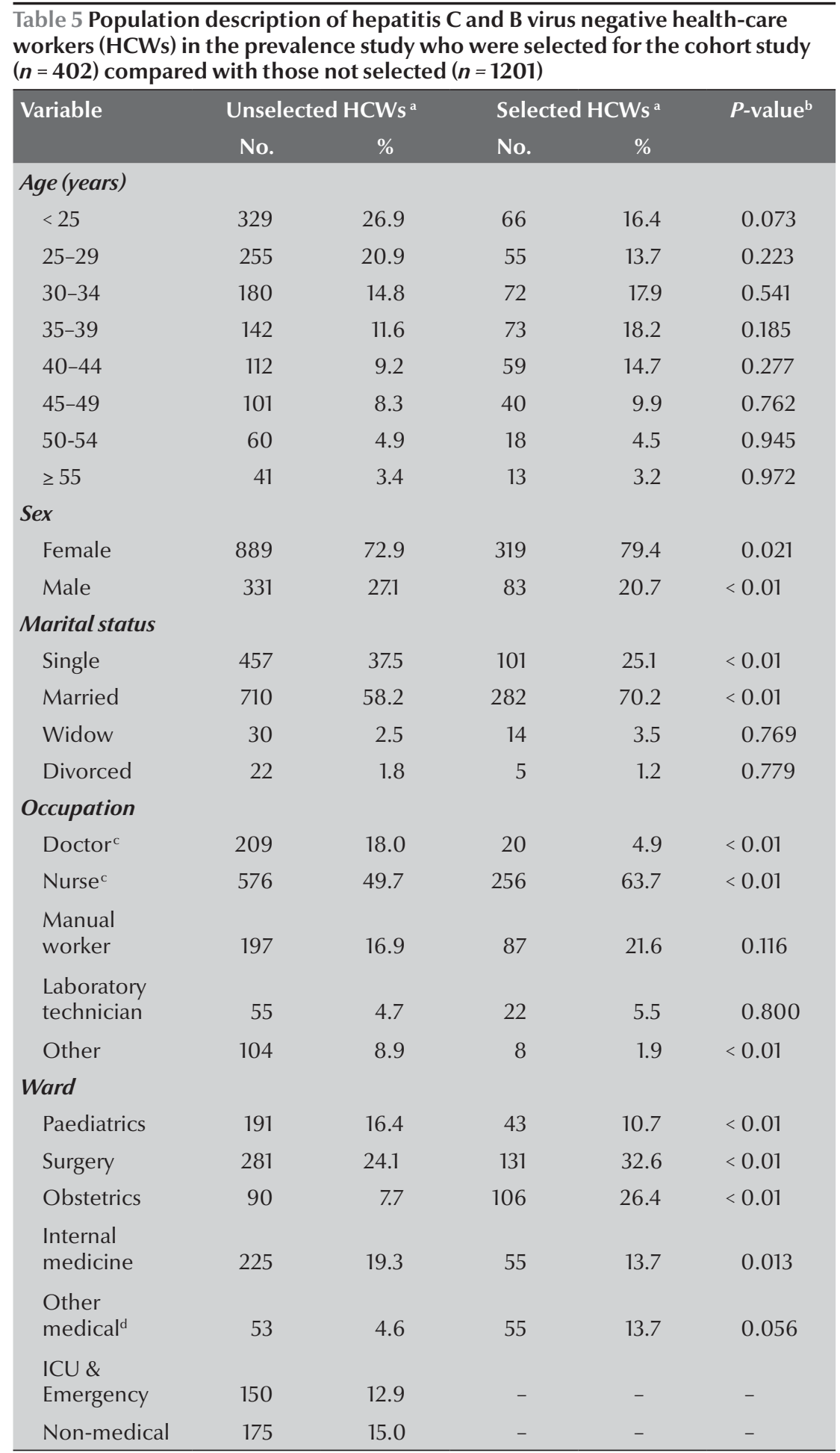

${ }^{a}$ Both groups tested negative for hepatitis C and B virus at baseline; ${ }^{b}$ Two-sample test of proportion. 'Includes physicians-in-training, nurses-in-training, resident and senior doctors and nurses; ${ }^{d}$ Includes Cardiology, Pulmonary disease, Geriatrics, Tropical medicine and Nephrology. $I C U=$ Intensive care unit.

laboratory findings of the $4 \mathrm{HCV}$ incident cases are shown in Table 6. Two incident cases reported exposure to body fluids during follow-up; however, both confirmed the use of standard precautions.

\section{Discussion}

Our findings show a similar age-standardized anti-HCV prevalence among HCWs in ASUHs (8.1\%) compared with the population of greater Cairo 


\begin{tabular}{|c|c|c|c|c|}
\hline \multirow[t]{2}{*}{ Variable } & \multicolumn{4}{|c|}{ Case no. } \\
\hline & 1 & 2 & 3 & 4 \\
\hline \multicolumn{5}{|l|}{ Sociodemographic characteristics } \\
\hline Age (years) & 39 & 40 & 62 & 25 \\
\hline Sex & Female & Female & Male & Female \\
\hline Marital status & Married & Married & Married & Married \\
\hline Occupation & Nurse & Nurse & $\begin{array}{l}\text { Manual } \\
\text { worker }\end{array}$ & Nurse \\
\hline \multicolumn{5}{|l|}{ Risk exposures } \\
\hline \multicolumn{5}{|l|}{ Exposures in previous 6 months ${ }^{a}$} \\
\hline Surgical operation & No & No & No & No \\
\hline Hospital admission & No & No & No & No \\
\hline Received any injection & No & No & No & No \\
\hline Shaved at barber & $\mathrm{n} / \mathrm{a}$ & $\mathrm{n} / \mathrm{a}$ & No & $\mathrm{n} / \mathrm{a}$ \\
\hline Received blood & No & No & No & No \\
\hline Received dental treatment & No & No & No & No \\
\hline Child delivery & No & No & $\mathrm{n} / \mathrm{a}$ & No \\
\hline Used invasive contraception & No & No & $\mathrm{n} / \mathrm{a}$ & No \\
\hline Percutaneous blood exposure & No & No & No & No \\
\hline Exposure to body fluids & No & No & Yes & Yes \\
\hline \multicolumn{5}{|l|}{ Infection control } \\
\hline Use of standard precautions & No & No & Yes & Yes \\
\hline Received HBV vaccination & No & No & No & No \\
\hline \multicolumn{5}{|l|}{ Laboratory findings } \\
\hline \multicolumn{5}{|l|}{ HCV EIA } \\
\hline At enrolment & - ve & - ve & - ve & $-v e$ \\
\hline At 12-month follow-up & +ve & $-\mathrm{ve}$ & +ve & $-v e$ \\
\hline At 18-month (last) follow-up & +ve & +ve & +ve & $+\mathrm{ve}$ \\
\hline \multicolumn{5}{|l|}{ HCV PCR } \\
\hline At enrolment & - ve & $-\mathrm{ve}$ & -ve & $-v e$ \\
\hline At 12-month follow-up & -ve & - ve & +ve & $-v e$ \\
\hline At 18-month (last) follow-up & $-v e$ & $-v e$ & $+\mathrm{ve}$ & - ve \\
\hline
\end{tabular}

${ }^{a}$ Self-reported exposures at the second (last) follow-up visit, 18 months post-enrolment. $n / a=$ not applicable; $H B V=$ hepatitis $B$ virus; $H C V$ EIA = anti-hepatitis $C$ virus antibody testing using enzyme immunoassay; HCV PCR = hepatitis C virus RNA testing using polymerase chain reaction assay; -ve/+ve= negative/positive test result.

$(10.4 \%)(P=0.127)$. Factors independently associated with anti-HCV seropositivity were: age (OR 2.01 for a 10 -year increment of age), large number of blood transfusions (OR 5.9), treatment of bilharziasis with parenteral antischistosomal therapy (OR 6.3) and being a manual worker (OR 4.3).

This study provides insights into the seroprevalence and incidence of $\mathrm{HCV}$ infection among HCWs in Egypt, a group at particular high risk given the substantial evidence on health-care-related transmission of $\operatorname{HCV}(5,6,14)$. Estimates of HCV seroprevalence among HCWs worldwide vary from $0.28 \%$ to $4.1 \%(15-17)$. There are limited data available from similar settings in Egypt. One study by El Gohary et al. in a rural community reported anti-HCV prevalence of $7.7 \%$ (6/78) among HCWs (10). Abdelwahab et al. reported anti-HCV prevalence of $16.6 \%$ among
HCWs at the National Liver Institute in the Nile Delta (11), which was comparable to the background prevalence in the general population of the Nile Delta. Munier et al. recently reported a baseline anti-HCV seroprevalence of 7.2\% (95\% CI: 5.3-10.0\%) among a cohort of HCWs in ASUHs who had been exposed to needle-stick injuries from HCV-infected patients (18).

The 2008 Egypt Demographic and Health Survey data provided a valuable source to compare the $\mathrm{HCV}$ prevalence of the population of greater Cairo with our study population; both were conducted in urban settings, in contrast to most seroprevalence studies in Egypt, which took place in rural populations. The HCV prevalence among HCWs was similar to that of the Cairo population, which is surprising since those working at ASUHs are exposed to a highly viraemic HCV patient population; the prevalence of HCV RNA among patients at ASUHs was reported to be $37 \%$ in the study of Munier et al. (18). This result was also described by Moens et al. in a large cross-sectional survey of Belgian HCWs, in which the prevalence among HCWs was not higher than in the general population (19). We therefore propose a hypothesis - one that was also elaborated in several studies (20-22) including in Egypt $(18,23-25)$ - that a higher cell-mediated immune response against $\mathrm{HCV}$ in HCWs who are repeatedly exposed would partially protect them against infection.

The HCV incidence shown in this study (7.3 per 1000 person-years) is among the first estimates in a healthcare setting in Egypt. Since there were only 4 seroconversions, the $95 \%$ CI of the incidence was large (2.7-19.4 per 1000 person-years). Our figures are consistent with those observed in other HCWs settings, for example in Abdelwahab et al.'s study (2.04 per 1000 person-years; 95\% CI: 0.25-7.37) (25) or at the national level (2.0 per 1000 person-years) (26). However, estimates 
of HCV incidence at the national level are still subject to investigation and may not be well understood.

As to risk factors of HCV seropositivity, our work showed a more than 4-fold increase in HCV seroprevalence among manual workers, who are mostly of lower socioeconomic background and a poor level of education [a known risk factor for HCV infection (3) ] compared with medical doctors. A similar finding was observed among manual workers in the study of Abdelwahab et al., in which occupational exposures were also not found to be associated with HCV infection, suggesting an underlying community-based transmission rather than occupational exposure (10). Consequently, we hypothesize a probable association between the lower level of education of manual workers and HCV infection, which has been shown in the results of the Egypt Demographic and Health Survey in 2008 (3), in both urban and rural settings. Other possible explanations, for which socioeconomic conditions may have represented a proxy, include access to poor-quality health-care settings (in which infection control practices are likely to be feeble), as well as population migration from regions of high endemicity for $\mathrm{HCV}$.

We confirmed the well-known association between parenteral antischistosomal therapy and HCV infection in Egypt $(4,14,27)$, with a more than 6-fold increase of HCV seropositivity in HCWs who reported having received parenteral antischistosomal therapy during their lifetime. However, this risk was related to older age groups and our study population was young (mean age 34 years) and only
$5 \%$ of HCWs had previously received parenteral antischistosomal therapy and/or tablets; therefore this risk factor would translate into a low attributable risk of $\mathrm{HCV}$ infection among HCWs. Having received a large number of blood transfusions was associated with $\mathrm{HCV}$, though the attributable fraction of HCV seropositivity would again be very small in our study population, as only $7 \%$ of HCWs had ever received blood transfusions.

There are a few limitations surrounding our findings. First, we used convenience sampling in recruiting HCWs for the cross-sectional survey, which may have caused selection bias. This was evident in the under-representation of physicians-in-training. Since physicians-in-training in our study setting had the highest occupational blood exposure rates (18), their under-representation in the survey sample would bias our estimates towards the null. Thus, selection bias may explain the absence of an association between occupational exposures and HCV infection. Alternatively, if cell-mediated immunity had been an important component of protection against HCV infection, it would hinder any possible association with occupational exposures, since highly exposed HCWs would be protected against $\mathrm{HCV}$. Secondly, the premature cessation of recruitment in the cohort study resulted in an inadequate sample size to estimate $\mathrm{HCV}$ incidence, as well as an insufficiently representative sample in comparison with those not selected from the sampling frame. Finally, other sources of bias, including recall bias, may have caused a misclassification of exposure characteristics. In addition, the cross-sectional design has inherent limitations when addressing the temporal association between exposures and outcomes.

\section{Conclusion}

To conclude, we found similarly high rates of HCV seroprevalence among HCWs at ASUHs compared with the general population of Cairo. One possible explanation for this similarity may be related to cellular immunity protection against low-dose exposures to $\mathrm{HCV}$ infection, as was suggested in previous studies conducted in Egypt. Our findings also suggest considerable ongoing HCV incidence among HCWs. Finally, there was a high number of sharps injuries among HCWs, raising again the importance of improving implementation of and compliance to safe injections practices in health-care settings.

\section{Acknowledgements}

The authors thank with great appreciation the great efforts provided by the members of the infection control team at ASUHs in data collection and the team of physicians-in-training who volunteered to participate in recruitment and counselling of HCWs. Also, the authors wish to dedicate this work to the late Professor Mostafa Kamal, without his unwavering support this work would not have been complete.

Funding: The study received funding from Ain Shams University annual research fund, issued 21 January 2008 for a period of 4 years

Competing interests: None declared.

\section{References}

1. Hepatitis C. Fact sheet No. 164 [Internet]. World Health Organization. July 2013. (http://www.who.int/mediacentre/ factsheets/fs164/en/, accessed 2 February 2015).

2. El-Zanaty F, Way A. Egypt Demographic and Health Survey 2008. Cairo: Ministry of Health, El-Zanaty and Associates, and Macro International; 2009.
3. Guerra J, Garenne M, Mohamed MK, Fontanet A. HCV burden of infection in Egypt: results from a nationwide survey. J Viral Hepat. 2012 Aug;19(8):560-7. Epub 2012 Feb 6 PMID:22762140

4. Frank C, Mohamed MK, Strickland GT, Lavanchy D, Arthur RR, Magder LS, et al. The role of parenteral antischistosomal 
therapy in the spread of hepatitis C virus in Egypt. Lancet. 2000 Mar 11;355(9207):887-91. PMID:10752705

5. Mohamoud YA, Mumtaz GR, Riome S, Miller D, Abu-Raddad LJ. The epidemiology of hepatitis $C$ virus in Egypt: a systematic review and data synthesis. BMC Infect Dis. 2013;13:288. PMID:23799878

6. Mohsen A, Bernier A, LeFouler L, Delarocque-Astagneau E, ElDaly $\mathrm{M}$, El-Kafrawy $\mathrm{S}$ et al. Hepatitis $\mathrm{C}$ virus acquisition among Egyptians: analysis of a 10-year surveillance of acute hepatitis C. Trop Med Int Health. 2015 Jan;20(1):89-97. PMID:25336067

7. Lee R. Occupational transmission of bloodborne diseases to healthcare workers in developing countries: meeting the challenges. J Hosp Infect. 2009 Aug;72(4):285-91. PMID:19443081

8. Talaat M, Kandeel A, El-Shoubary W, Bodenschatz C, Khairy I, Oun S, et al. Occupational exposure to needlestick injuries and hepatitis $B$ vaccination coverage among health care workers in Egypt. Am J Infect Control. 2003 Dec;31(8):469-74. PMID:14647109

9. Prüss-Ustün A, Rapiti E, Hutin Y. Estimation of the global burden of disease attributable to contaminated sharps injuries among health-care workers. Am J Ind Med. 2005 Dec;48(6):482-90. PMID:16299710

10. El Gohary A, Hassan A, Nooman Z, Lavanchy D, Mayerat C, el Ayat A, et al. High prevalence of hepatitis $C$ virus among urban and rural population groups in Egypt. Acta Trop. 1995 May;59(2):155-61. PMID:7545863

11. Abdelwahab S, Rewisha E, Hashem M, Sobhy M, Galal I, Allam WR, et al. Risk factors for hepatitis $C$ virus infection among Egyptian healthcare workers in a national liver diseases referral centre. Trans R Soc Trop Med Hyg. 2012 Feb;106(2):98-103. PMID:22197011

12. Talaat M, Kandeel A, Rasslan O, Hajjeh R, Hallaj Z, El-Sayed $\mathrm{N}$, et al. Evolution of infection control in Egypt: achievements and challenges. Am J Infect Control. 2006 May;34(4):193-200. PMID:16679176

13. Abdel-Hamid M, Edelman DC, Highsmith WE, Constantine NT. Optimization, assessment, and proposed use of a direct nested reverse transcription-polymerase chain reaction protocol for the detection of hepatitis C virus. J Hum Virol. 1997 NovDec;1(1):58-65. PMID:10195232

14. Arafa N, El Hoseiny M, Rekacewicz C, Bakr I, El-Kafrawy S, El Daly $M$, et al. Changing pattern of hepatitis $C$ virus spread in rural areas of Egypt. J Hepatol. 2005 Sep;43(3):418-24. PMID:16019104

15. Thorburn D, Dundas D, McCruden EA, Cameron SO, Goldberg DJ, Symington IS, et al. A study of hepatitis C prevalence in healthcare workers in the West of Scotland. Gut. 2001 Jan;48(1):116-20. PMID:11115832

16. Libanore $M$, Bicocchi $R$, Ghinelli F, Palumbo G, Moretti $M$, Pazzi $P$, et al. Prevalence of antibodies to hepatitis $C$ virus in Italian health care workers. Infection. 1992 Jan-Feb;20(1):50. PMID:1373408
17. Polish LB, Tong MJ, Co RL, Coleman PJ, Alter MJ. Risk factors for hepatitis $C$ virus infection among health care personnel in a community hospital. Am J Infect Control. 1993 Aug;21(4):196200. PMID:7694529

18. Munier A, Marzouk D, Abravanel F, El-Daly M, Taylor S, Mamdouh $\mathrm{R}$, et al. Frequent transient hepatitis $\mathrm{C}$ viremia without seroconversion among healthcare workers in Cairo, Egypt. PLoS One. 2013;8(2):e57835. PMID:23469082

19. Moens G, Vranckx R, De Greef L, Jacques P. Prevalence of hepatitis $C$ antibodies in a large sample of Belgian healthcare workers. Infect Control Hosp Epidemiol. 2000 Mar;21(3):20912. PMID:10738992

20. Semmo N, Barnes E, Taylor C, Kurtz J, Harcourt G, Smith N, et al. T-cell responses and previous exposure to hepatitis $C$ virus in indeterminate blood donors. Lancet. 2005 Jan 2228;365(9456):327-9. PMID:15664228

21. Post JJ, Pan Y, Freeman AJ, Harvey CE, White PA, Palladinetti P, et al.; Hepatitis $C$ Incidence and Transmission in Prisons Study (HITS) Group. Clearance of hepatitis C viremia associated with cellular immunity in the absence of seroconversion in the hepatitis $C$ incidence and transmission in prisons study cohort. J Infect Dis. 2004 May 15;189(10):1846-55. PMID:15122521

22. Takaki A, Wiese M, Maertens G, Depla E, Seifert U, Liebetrau A, et al. Cellular immune responses persist and humoral responses decrease two decades after recovery from a single-source outbreak of hepatitis C. Nat Med. 2000 May;6(5):578-82. PMID:10802716

23. Abdelwahab SF, Zakaria Z, Sobhy M, Rewisha E, Mahmoud MA, Amer MA, et al. Hepatitis C virus-multispecific T-cell responses without viremia or seroconversion among Egyptian health care workers at high risk of infection. Clin Vaccine Immunol. 2012 May;19(5):780-6. PMID:22441392

24. Hashem M, El-Karaksy H, Shata MT, Sobhy M, Helmy H, El-Naghi S, et al. Strong hepatitis C virus (HCV)-specific cellmediated immune responses in the absence of viremia or antibodies among uninfected siblings of HCV chronically infected children. J Infect Dis. 2011 Mar 15;203(6):854-61. PMID:21257736

25. Abdelwahab SF, Hashem M, Galal I, Sobhy M, Abdel-Ghaffar TS, Galal G, et al. Incidence of hepatitis C virus infection among Egyptian healthcare workers at high risk of infection. J Clin Virol. 2013 May;57(1):24-8. PMID:23375237

26. Breban R, Doss W, Esmat G, Elsayed M, Hellard M, Ayscue P, et al. Towards realistic estimates of HCV incidence in Egypt. J Viral Hepat. 2013 Apr;20(4):294-6. PMID:23490375

27. Rao MR, Naficy AB, Darwish MA, Darwish NM, Schisterman E, Clemens JD, et al. Further evidence for association of hepatitis C infection with parenteral schistosomiasis treatment in Egypt. BMC Infect Dis. 2002 Dec 4;2:29. PMID:12464161 